доктор техн. наук, професор, заслужений діяч науки і техніки України ORCIDID 0000-0003-0326-7088

Національній технічний університет України «Київський політехнічний інститут імені Ігоря Сікорського»

\title{
ПРО НОВУ ПАРАДИГМУ ФОРМУВАННЯ ПОНЯТТЯ ЕКОНОМІЧНОГО ПРОСТОРУ ІННОВАЦІЙНИХ БІЗНЕС-СТРУКТУР
}

\section{О НОВОЙ ПАРАДИГМЕ ФОРМИРОВАНИИ ПОНЯТИЯ ЭКОНОМИЧЕСКОГО ПРОСТРАНСТВА ИННОВАЦИОННЫХ БИЗНЕС-СТРУКТУР}

\section{ABOUT THE NEW PARADIGM TO THE FORMATION OF ECONOMIC SPACE THE INNOVATION BUSINESS-STRUCTURES}

В статті висвітлені результати аналітико-експериментальних досліджень нової парадигми та проблеми формування поняття економічного простору як подальшої основи досліджень иіннісно-часової та структурно-просторової динаміки економікоінформаційних $i$ виробничих структур інноваційних систем, їх характеристик $i$ закономірностей в економічних системах п'яти рівнів. Розглянуто зміст досить багатьох новачій щуодо опису економічного простору, які неодмінно націлені на конкретне осягнення реальних економічних процесів та по типу підходу зовсім протилежний сучасному розумінню такого простору як геометричного. Завдання полягало у тому, щчоб продемонструвати такі підходи до проблеми, які можуть породжувати отримання нових $i$ навіть неочікуваних наукових результатів у майбутньому.

Автором статті вперше продемонстровано такі підходи до можливих рімень наукової проблеми формування економічного орієнтованого простору, які можуть породжувати отримання нових $i$ навіть неочікуваних наукових результатів $у$ майбутньому. Розглянуто зміст досить багатьох новацій щодо опису економічного простору, які неодмінно націлені на конкретне осягнення реальних економічних процесів та по типу підходу зовсім протилежний сучасному розумінню такого простору як геометричного.

Перспективою подальших наукових розробок за даним напрямом дослідження $\epsilon$ формування комплексної методології оцінювання стану розвитку економічного простору інноваційних бізнес-структур.

Матеріал статті може бути рекомендований для подальшого використання як основу формування нової парадчгми формування понять економічного простору та теоретико-практичного застосування й розвитку інноваційно-орієнтованого управління на підприємствах різних галузей промисловості та інновачійних бізнес-структур.

Ключові слова: система, економіка, час, простір, вимір, орієнтованість

В статье освещены результаты аналитико-экспериментальных исследований новой парадигмы и проблемы формирования понятия экономического пространства как дальнейтей основы исследований ценностно-временной и структурно-пространственной динамики экономико-информационных и производственных структур инновационных систем, их характеристик и закономерностей в экономических системах пяти уровней. 
Рассмотрено содержание довольно многих новаций относительно описания экономического пространства, которые непременно нацелены на конкретное постижение реальных экономических прочессов и по типу подхода совершенно противоположный современному пониманию такого пространства геометрического. Задача состояла в том, чтобы продемонстрировать такие подходы к проблеме, которые могут порождать получение новых и даже неожиданных научных результатов в будущем.

Автором статьи впервые продемонстрировано такие подходы к возможных решений научной проблемь формирования экономического ориентированного пространства, которые могут порождать получение новых и даже неожиданных научных результатов в будущем. Рассмотрено содержание довольно многих новаций относительно описания экономического пространства, которые непременно начелены на конкретное постижение реальных экономических прочессов и по типу подхода совершенно противоположный современному пониманию такого пространства геометрического.

Перспективой дальнейших научных разработок по данному направлению исследования является формирование комплексной методологии оценки состояния развития экономического пространства инноваџионных бизнес-структур.

Материал статьи может быть рекомендован для дальнейшего использования как основу формирования новой парадигмы формирования понятий экономического пространства и теоретико-практического применения и развития инновачионноориентированного управления на предприятиях различных отраслей промышленности $и$ инновационных бизнес-структур.

Ключевые слова: система, экономика, время, пространство, измерение, ориентированность

The article describes the results of analytical and experimental investigations of a new paradigm and problems of formation of the concept of economic space as the further basis for research of values-temporal, structural and spatial dynamics of economic information and production structures of innovation systems, their characteristics and regularities in the economic systems of five levels. Reviewed the content of quite a few innovations on the description of the economic space, which will necessarily focus on a particular comprehension of the real economic processes and the type of approach is totally opposite to the modern understanding of this geometric space. The task was to demonstrate these approaches to the problem, which may give rise to new and even unexpected scientific results in the future.

The author first demonstrated these approaches to possible solutions of scientific problems of formation of economic-oriented spaces, which can give rise to new and even unexpected scientific results in the future. Reviewed the content of quite a few innovations on the description of the economic space, which will necessarily focus on a particular comprehension of the real economic processes and the type of approach is totally opposite to the modern understanding of this geometric space.

The prospect of further scientific developments in this field of research is the development of a comprehensive methodology of assessing the development of economic space of innovative business structures.

The article can be recommended for further use as a basis for the formation of a new paradigm of formation of the concepts of economic space and the theoretical and practical application and development of innovation-oriented management at the enterprises of various industries and innovative business structures.

Keywords: system, economy, time, space, dimension, focus 
Вступ. Процеси перетворення соціально-економічного простору i пов'язані з цим потужні наукові теорії аналізувати та розуміти стає дедалі складніше.

Звернемось для деяких пояснень цієї проблеми до цитати видатного політолога, футуролога і економіста Френсіса Фукуями: «Сучасна економіка це процес індустріалізації, детермінований сучасною наукою, що змушує до гомогенізаиії людства і попутно руйнує широкий спектр традиційних культур. Проте він не може виходити переможцем у кожній битві, зіштовхуючись іноді 3 такими культурами і проявами тімосу, які важко уявити» [1].

На слова-категорії тімос (духовність) $i$ гомогенізація (зменшення гетерогенності) в цій цитаті звернули свою увагу І. К Бистряков i Ю. М. Манцевич [2], які зосередились на деяких принципових методологічних аспектах їх використання при визначенні поняття соціально-економічного простору, пов'язавши його із простором духовним. Вони віднесли категорію духовного простору до поліморфного складу соціально-економічного простору для відображення складних систем і на цій основі зробили висновок про необхідність визначати процес формування поняття економічного простору (у тому числі i для відображення інноваційних бізнес-структур) як композиційний на засадах врахування духовних проявів об'єктивних явищ в частині творчого підходу до процесу формування, у нашому випадку творення простору.

Продовжуючи аналіз думок І. К Бистрякова і Ю. М. Манцевича [2], знаходимо спів падіння в них з нашою позицією про те, що потребують визначення категорії простір $i$ просторовий розвиток. Тобто, простір як категорія мислення в економічній i теорії, i практиці все більше відокремлюється від свого видимого матеріального територіального образу, що починає розглядатись суб'єктами господарювання не як гомогенне явище скалярного типу, а як явище гетерогенне, якому властивий векторний тип функиіонування на базі просторово-орієнтованих методологічних позицій.

Доцільно також при формуванні поняття економічного простору врахувати приклади еволюції таких інноваційних бізнес-структур, як кластер, (певний виробничий комплекс), та усвідомити те, що усе частіше його відображають, як кластерну стратегію, ту, що грунтується на центрах ділової активності із динамічною нелінійною поведінкою при управління просторовими цілями - категорію інтересу суб'єкту господарювання.

Отже, І. К. Бистряков і Ю. М. Манцевич [2] далі відзначили дуже важливу думку про те, що про новизну зазначеної дослідницької парадигми свідчить той факт, що у світовому господарському процесі виникла потреба в оперуванні не окремими територіями, як традиційними поняттями 
економічного простору, до яких ми так звикли, а матеріально-технічними потоками.

В нашому розумінні до цих потоків слід додати поняття і иінністночасових, і економіко-інформачійних потоків в економічному просторі.

Завдяки результатам досліджень І. К. Бистрякова і Ю. М. Манцевича [2], можна зробити ряд висновків щодо рівня розкриття методології просторової парадигми розвитку економічних систем із таких робіт вітчизняних та зарубіжних учених як [3-6], зокрема, те, що при формування поняття економічного простору слід нематеріальну (духовну) складову підняти до рівня теперішнього домінування матеріальної (технологічно-фінансової) складової. Тобто, завести їх в економічний простір принаймні рівноправними.

Таким чином, проблема формування сучасного поняття «економічний простір» є актуальною.

Ця проблема повинна почати вирішуватись із врахуванням інтересів та складності просторового різноманіття діяльності людини не в контексті фізичного уявлення «простір-час» із евклідовою метрикою, а в контексті уявлень і понять економіко-інформаційного простору із цінністно-часовою метрикою.

Навряд чи коли-небудь стане задовільним такий спосіб розуміння економічних істин, при якому вони постають у вигляді складних ланцюжків формальних міркувань і обчислень, коли ми змушені, так би мовити, наосліп, на дотик переходити від однієї ланки вирішення проблеми до іншого, долаючи не тільки бар'єри здорового практичного глузду, але і лексикографічні наукові бар'єри.

В умовах сучасного світового економічного «хаосу» ми хотіли б заздалегідь бачити кінцеву мету і що до неї веде шлях сталого розвитку систем, що вироджуються, завдяки існуванню ефектів самоорганізованої критичності в рамках ціннісно-часової системи координат економікоінформаційного простору для визначення розмірності параметрів нематеріальної потужності економічних систем. Для поглиблення розуміння читача цього нового поняття пропоную звернутись до наступних робіт автора [7-10].

Маючи нову парадигму, ми хотіли б зрозуміти внутрішні об'єктивні підстави, що визначають хід подій, ідеї їх інтерпретацій, більш глибокі взаємозв'язки економічних процесів на основі природних симетрій, нелінійної динаміки, ієрархічної складності економічних систем.

3 сучасними економічними теоріями справа йде так само, як сучасною машинною або експериментальною фізичною схемою: прості основні 
об'єктивні принципи лежать глибоко і ледь помітні під оболонкою дрібних економічних деталей.

Незаперечні докази всіх, близьких до істинних, економічних тверджень, безсумнівно, є наріжним каменем будь-якої економічної теорії. Це, на мою думку, стосується і проблеми формування нелінійних теорій й динаміки параметрів процесів і станів економічного орієнтованого простору.

Зрозуміло, економічна практика і реальне життя світового суспільства, сама судить, в яких випадках економічній теорії варто поступитися строгістю доказів. Одвічний секрет надзвичайної наукової удачі і тепер постає в умінні автора будь-якої економічної теорії знаходити об'єктивно нові, поставлені життям проблеми, інтуїтивно передбачати і формулювати гіпотези, доведення яких призводить до нових значних результатів і до встановлення важливих взаємозв'язків явищ і процесів в економіці.

Методологія. Прийнятий для досліджень поставленої проблеми аналітико-індуктивний метод свідчить про те, що не будь нових концепцій, нових цілей, економіка 3 властивою ій в 21-му столітті математичною строгістю формалізацій, незабаром би вичерпала себе і прийшла в занепад, бо весь матеріал логіки був би витрачений і вийшов би на рівень тривіальних повторень.

У цьому сенсі можна сказати, що рухають економіку вперед в основному ті, хто відзначений дякуючи інтуїції, а не суворим доведенням. У методиці поглиблення розуміння процесів економіки через нові теорії лежить саме це інтуїтивне (духовне, нематеріальне) осягнення тих внутрішніх взаємозв'язків і відносин, підстави яких різні, і є основним, але там, де потрібно напружити всю міць хитрощів логіки, певною мірою інтуїція перед логікою змушена відступити.

Відомо практично всім й досить давно, що «редукиіонізм», як один із підходів до формування та дослідження функціонування моделей простору полягав у тому, що при підході з позиції редукціонізму будь-який простір, як систему, дослідник розбивав на окремі частини (складові частини) і вивчав ці частини, як сукупність, так і окремо кожну для того, щоб зрозуміти діяльність такої системи в цілому.

Однак редукціонізм випускав з уваги важливу діалектичну сутність, у тому числі, щодо економічного орієнтованого простору, наявність у ньому складних процесів взаємодії між частинами, а саме у цих процесах і полягає сенс існування і самих частин.

Таку можливість відкрив метод, що прийшов на зміну редукціонізму в останні 10-15 років у світовій практиці досліджень економічного простору - це «холізм». Холізм, який логічно продовжує й розвиває «редукиіонізм», 
передбачає, що система - це щось більше, ніж сума складових іiі частин. Звичайно, холізм вивчає і частини системи, але для нього важливіше розуміти, яку роль ці частини відіграють у функціонуванні системи як ціле.

Для цього слугує i наша концепція економічного орієнтованого простору, яка полягає в проведенні аналогії його із множиною натуральних чисел та спирається на можливість конструктивного відображення у континуумі місцеположення всіх елементів множин (places) знаковими конструкціями.

Аналізуючи континуум, яким є у нашому випадку економічний простір, у цьому дослідженні ми використаємо на відміну від звичайного, більш загальний підхід, чим вимір координат, і застосуємо топологічну точку зору, відповідно до якого два континуума, які отримуємо один із другого шляхом безперервної деформації, що співпадають.

Нижче, при розгляді одновимірного економічного простору цей підхід буде втілений знаками, які дозволять нам локалізувати точки в одновимірному континуумі - прямій, це дійсні та комплексні числа. При чому, для функцій комплексних змінних ми віддаємо перевагу замкнутому одновимірному континууму - окружність.

Далі, як для одновимірного орієнтованого, так і для $2-x, 3-x, ;-x, \ldots, n$ вимірного орієнтованих континуумів-просторів найбільш важливою $\epsilon$ прийнята нами аксіома-принцип, що полягає у тому, що простори завжди припускають розбиття на частини. В силу апріорності таких знакових конструкцій ми говоримо про кількісний аналіз економічних процесів для різного рівня економічних систем, тобто різноманіть. Я впевнений, що слово «кількісний», якщо взагалі можливо надати який небудь зміст, належить розуміти у широкому сенсі.

Потужність економічних систем, як свідчить розвиток сучасної економічної науки, за своєю суттю спирається в нашій теорії на комбінацію апріорних знакових конструкцій $з$ одного боку і на дані систематичного досвіду в формі практичних результатів діяльності економічних систем, принаймні п'яти рівнів, у формі запланованих та втілених у практику reactions та статистичних вимірів. Із цього приводу в цитаті із трактату Галілея «Пробірних справ майстер», що наводиться в роботі Karla Vosslera [11], можна зрозуміти, що «...величну книгу природи (у тому числі і соиіально-економічних nроиесів та подій) може читати лише той, хто спочатку навчиться осягати іiі мову i тлумачити знаки, якими вона написана. Написана вона ж на мові математики, і їі знаки - трикутники, круги та інші геометричні фігури, без яких людина не зміг би зрозуміти в ній ні єдиного слова». 
Результати дослідження. В наш час ми знаємо, що ні один із елементів (features) нашого безпосереднього сприйняття (observation), навіть простір i час, не може бути збережений у світі досліджень у натуральному вигляді фізичних чи економічних сутностей, якщо воно претендує на справжню об’єктивність, i, кінець кінцем, прийшли до необхідності прийняти чисто знакову комбінаторну конструкцію. Можна припустити, що для економіста практично також, як для математика - тополога, байдужий конкретний спосіб використання певної комбінаторної схеми послідовного розбиття (декомпозиції) до того континууму економічних подій «тут-тепер», який ми називаємо оточуючим світом.

Зрозуміло, що теоретичні конструкції в той чи інший спосіб необхідно співставляти із фактами, що спостерігаються. Історичний розвиток наших економічних теорій, що відбувається завдяки евристичним міркуванням, вказує, що це звивистий і багатоступінчастий шлях, який призведе нас від досвіду до певних топологічних конструкцій економічного простору.

Однак дане системне викладення нашого підходу побудовано інакше: спочатку нами пропонується деяка теоретична конструктивно-аксіоматична основа, що не робить спроб ототожнювати за допомогою окремих вимірів знаки, які до неї входять, із иіннісно-часовими координатами економічних nодій. Ми зробимо спробу потім на одному диханні дати опис того, яким чином вся наша теорія потужності економічних систем вкладається в поняття топологічного економічного орієнтованого простору багатьох вимірів та співвідноситься із фактами спостереження ціннісно-часовими розмірностями економічних подій. Саме ізоморфні картини таких подій призводять до одних і тих же результатів в усьому, що стосується фактів, що спостерігаються.

Як методи досліджень і редукціонізм, і холізм вище представлений 3 боку конструктивного підходу. У вже опублікованих роботах автора використано також неконструктивний аксіоматичний метод. Його класичним прототипом $\epsilon$ аксіоми геометрії Евкліда. Аксіоматичний метод був використаний Архімедом, а потім Галілеєм і Гюгенсом при створенні науки механіки.

Використовуючи аксіоматичний метод в теорії потужності економічних систем автора [див. 7-10] всі наступні поняття спочатку визначені через декілька невизначуваних основних тверджень - аксіом, що відносяться до основних понять. В попередні часи існування точних наук (фізики, механіки, математики) творці теорій були схильні стверджувати апріорні очевидності своїх аксіом, але це епістемологічний аспект проблеми.

Тут зазначимо, що якщо гносеологія розгортає свої уявлення навколо опозиції «суб'єкт- об'єкт», то для епістемології базовою є опозиція «об'єкт - 
знання». Тому дедуктивний метод використано автором при подальшому формуванні поняття економічний орієнтований простір у відповідності до формальної логіки на основі силогістичних висновків, розуміючі, що, силогізм $\epsilon$ така форма умовиводу, в якому 3 двох суджень (основних понять - аксіом) необхідно випливає третє похідне поняття теорії, причому одне 3 двох даних суджень (аксіом) є загально-ствердною або загально-негативною.

Аксіоматично-дедуктивний метод геометричної творчості Евкліда, особливо в період століть раціоналізму, «Начала» Евкліда вважалися взірцем для всякої точної аргументації. Подібне аксіоматине викладення тоre geometrico для побудови економічних теорій автору поки що невідоме.

У нашому випадку це «Економічний простір, що показаний геометричним (топологічним) способом». Першу нашу аксіому-приниип, що полягає у тому, що економічні орієнтовані простори завжди припускають розбиття на частини, вже вище в цій статті було визначено.

Отже, прийняті в роботі методи досліджень, на наш погляд, виявляють собою майстерно складену суміш конструктивної та аксіоматичної процедур. Взаємопроникнення цих процедур, можливо, $є$ тим єдиним виходом 3 проблеми вибору одного із двох підходів у якості істинно достовірного способу мислення, а іншого у якості допоміжного. У нашому випадку зроблений підхід до методу взаємопроникнення процедур.

На такій новій точці зору можна припустити, що в дослідженні дійсно вдасться розвинути поняття економічного орієнтованого простору, як певного континууму, для формування моделей інноваційних бізнес-структур, чому й присвячені результати даних досліджень.

Але в чому ж секрет такого нового розуміння економіки? В науці нині знову загострюються спроби протиставити розуміння, герменевтику як основу наук про дух, природно-науковому поясненню, і навколо слів «інтуїція», «розуміння» виникає якийсь містичний ореол, як свідчення особливої глибини і безпосередності.

У сучасній економіці, на нашу думку, необхідно більи тверезо дивитися на реальні і уявні речі. Говорячи простою мовою, економічний орієнтований простір - це складний комплекс, наповнення якого як цілого залежить від характерних значень й вимірів параметрів складових його частин та від закономірностей взаємодії між цими частинами.

Такий економічний орієнтований простір повинен бути наділений метричною структурою та на першому місці - структурою порядку. Формуванню та розкриттю понять метричної структури і структури порядку $n$ - вимірного економічного орієнтованого простору, як певного континууму, для 
формування моделей інноваційних бізнес-структур й присвячені результати даних досліджень.

Отже, в новій парадигмі формування поняття економічного простору мова йде про мету, як одну з вирішальних характеристик сучасного прочесу "розуміння» можливих перетворень із систем в стані «хаосу» в системи, в яких виникають певні «атрактори» економічних иүілей.

Різні сторони економічних процесів, як предмета дослідження, ми піддаємо природному поділу шляхом їх уявної декомпозиції. Кожну сторону окремо досліджуємо, виходячи 3 особливого, порівняно вузького і набору припущень, що легко пояснюється, і потім повертаємося до цілого, відповідним чином об'єднуючи окремі результати в складну єдність.

Остання, синтетична частина процедури носить особливий характер i може міститись у наступному запропонованому нами новому розумінні економічного орієнтованого простору, у середовищі якого здійснюється як аналіз, декомпозиція, так і синтез нових наукових економічних результатів.

Проблема насамперед полягає в тому числі, щоб простежити взаємозв'язок між змістом лексикографічних інформаційних економічних конструкцій, тобто в економіці і інших гуманітарних науках це словесні визначення наукових економічних понять і графіко-схематичні креслення, із відповідністю однозначного «розуміння» їх змісту навіть фахівцями у сфері економіки та інших наук.

Автори економічних видань, книг і журналів, коли їм доводиться мати справу з економікою, повинні, а часто змушені вдаватися до різних порівнянь 3 реальними подіями і життєвими фактами, приводячи словесні описи і графічні (включаючи фото) таких фактів. Біда, однак, полягає в тому, що вони залишають читача в невіданні щодо того, наскільки точно їх (часто дотепні) аналогії передають суть справи і наукові сенси.

Приклад. «Ось лектор-економіст креслить на дошці деякі фігури, графіки економічних залежностей, схеми механізмів взаємодії елементів економічних систем i iн. й використовує невербальні візуальні образи; як далеко простягається використана лектором аналогія і яка гола істина стоїть за нею?»

В нашому випадку не можна не визнати, що креслення - не більше, ніж наочні образи, геометричні «картинки». Втім, як тільки ми замінимо креслення знаковою конструкцією, що складається з одних знаків, а інтуїтивне розуміння на економічний простір, в якому побудовані наші креслення, контури реальності проступлять у них. Тоді слова про те, що, наприклад, існує навколо нас якийсь $n$-вимірний економічний орієнтований простір, такий собі специфічний континуум, з фігурального обороту мовлення перетворюється на твердження, яке в буквальному сенсі є істинним. 
Йдучи по цьому шляху, легко зробити наступний крок і звернутися до абстракцій (моделей) і це саме той пункт, де неспеціаліст найчастіше перестає розуміти нас; інтуїтивна картина повинна поступитися місцем знаковій конструкції. Цей шлях також і в економічній науці в значній мірі належить математиці і математичній логіці.

Ще на початку 20-го століття А. Шпайзер з цього приводу писав [12]: «Своїми геометричними, а пізніше чисто математичними символьними конструкціями будь яка наука (зокрема $i$ економіка) скидає окови мови (лексики), і той, хто знає, яка гігантська праця вкладається в цей процес, i знайомий з його вражаючими успіхами, що незмінно повторюються, не може не відчути, що економічна наука наших днів (..., щ̧о побудована математичними символьними конструкціями), у своїй сфері інтелектуального світу, більш ефективна, ніж сучасні мови в їх жалюгідному стані і навіть музика в своїх областях».

Розглянемо першу альтернативу побудови економічного орієнтованого простору, прийнявши спочатку, що він $є$ деяка конструкція. Для цього визнаємо, що в такому підході системи аксіом лише встановлюють границі області значень тих змінних, які приймають участь в конструкції.

Пояснити це твердження можна на прикладах причинної структури $\mathrm{i}$ топології. Згідно спеціальній теорії відносності структури в об'єктивному світі, у тому числі серед цих структур й всі економічні реалії життя людей, причинна структура задана раз і назавжди й тому може бути побудована явно. Більш того, цю структуру розумно будувати разом із відповідним топологічним середовищем, подібно тому, як, наприклад, окружність (у нашому випадку, як різновид економічного орієнтованого простору) разом із своєю метричною структурою виходить шляхом нормального розбиття поділу дуги на дві рівні частини.

Однак в загальній теорії відносності причинна структура являє собою щось гнучке: вона повинна задовольняти деяким аксіомам, виведеним 3 досвіду та таким, що залишають достатню свободу. Але по мірі розвитку теорії економічного орієнтованого простору встановлюються закони природи (у тому числі, й соціально-економічні), що пов'язують гнучку причинну структуру із іншими гнучкими фізичними сутностями - розподілом маси, електромагнітним полем тощо, ці закони, в яких гнучкі явища виступають як змінні, у свою чергу виявляються результатом явних апріорних теоретичних побудов.

Релятивістська космологія вивчає топологічну структуру Всесвіту у цілому: відкритий Всесвіт чи замкнений і т. д. Зрозуміло, що топологічна структура не може бути настільки ж гнучкою, що і причинна структура, але 
перед тим, як спиратись на свідчення досвіду, вирішити, яка із топологічних можливостей втілюється в нашому реальному світі (у тому числі, й $y$ соціально-економічному середовищі, як частині цього світу) потрібно без перешкод оглянути всі ці можливості, а для цього потрібно звернутись до топології ( в нашому випадку в першу чергу до економічного орієнтованого простору).

В рамках цього простору топологічна схема була обмежена нами лише деякими аксіомами [7]. В цих обставинах виникла можливість витягти в рамках теорії потужності економічних систем ряд численних характеристик i встановити між різними рівнями систем співвідношення загального типу [8]. I зроблено це за допомогою побудови явної конструкції - п’яти-рівневої соціально-економічної системи [9], у якій довільні топологічні схеми входять у якості змінних.

Аксіоми, оскільки вони зустрічаються, слугують для встановлення границь області значень змінних в явно побудованих функціональних співвідношеннях. Якщо прийняти протилежну точку зору, то конструкція економічного орієнтованого простору, виявляється підлеглою аксіомам i дедукції, цей простір постає у вигляді системи аксіом, вибір яких залежать від ряду угод, які призводять до отримання із них заключень.

В повністю аксіоматизованій альтернативі власне «конструкції» відводиться другорядна роль: до неї звертаються при побудові прикладів, що створюють міст між чистою теорією і іï додатками. Іноді існує лише один приклад, тому аксіоми визначають певні економічні системи однозначно або принаймні із точністю до ізоморфізмів; у цьому випадку необхідність переходу від аксіоматичної структури до деякої явної конструкції економічного орієнтованого простору стає особливо настійною.

Ще більш суттєво треба відмітити, що хоча аксіоматична система й не передбачає побудову економічних орієнтованих просторів, як математичних об'єктів, вона, комбінуючи і неодноразово використовуючи логічні правила, будує математичні судження стосовно конструкції економічного орієнтованого простору. Дійсно, отримання наслідків із заданих посилок в рамках формальної логіки відбувається звичайно по певним логічним правилам, які, доречи, з часів Арістотеля неодноразово намагались звести в єдиний повний перелік, зробити його універсальним.

Таким чином, на рівні суджень аксіоматичний метод $\epsilon$ чистий конструктивізм. Ще понад 100 років тому світовий вчений Давид Гільберт довів аксіоматичний метод до гіркого кінця, коли судження математики, включаючи аксіоми, перетворились в формули і гра в дедукцію звелась до 
виводу із аксіом тих чи інших формул по правилам, що не враховують сенсу формул.

Пізніше за півстоліття К. Гьодель довів, що завжди знайдуться конструктивно очевидні арифметичні судження, які не виводяться із аксіом, як би ви їх не формулювали, і в той же час аксіоми, що безроздільно правлять всіма тонкощами конструктивної безкінечності, виходять за межі того, що може бути підтверджене досвідом.

На радість можливостям вдалого формування теорії економічного орієнтованого простору це не загрожує. Тому що, саме аксіоматичний метод дав можливість визначити межі і масштаби ціннісно-часових економічних подій для їх опису за допомогою економічного орієнтованого простору.

Отже, економічні події зовнішнього світу відбуваються у часі і просторі, що визначається вибраними аналітичними підходами до інтерпретації цих подій. Тому, значну частину економічних досягнень, які отримує людство разом і всередині природних і техногенних систем, можливо характеризувати шляхом опису їх просторових станів і часових подій величинами, що записуються у вигляді функцій ціннісно-часових координат, а останні виступають у якості незалежних змінних. При цьому виникає декілька можливостей сформувати ряд підходів до побудови моделей економічного простору.

Зазвичай, коли мова йде про простір, вважається що це тривимірний простір, у якому ми живимо. Більш складним є поняття $n$-вимірного простору $(n=1,2, \ldots)$, яким переважно користуються математики й розуміють його як сукупність елементів (можливо, певну множину складових елементів систем, у тому числі й економічних), що представляються у вигляді лінійних комбінацій цих елементів. Число виділених елементів слугує важливою характеристикою простору і співпадає із його розмірністю. Сукупність усіх виділених елементів n-вимірного простору математики називають його базисом.

Отже, на основі аксіоматично-дедуктивного методу досліджень далі сформулюємо основні поняття економічного орієнтованого простору.

Одновимірний економічний орієнтований простір. Першим варіантом моделі такого економічного простору, який демонструє наявність метричної структури і структури порядку 1 - вимірного економічного простору можна вважати пряму лінію. ÏÏ метрична структура визначається відстанню між двома точками. Якщо виділити на прямій довільно вибраний відрізок, можна прийняти його довжину за 1 (одиницю). Далі цій одиниці можна призначити будь-яку розмірність економічної величини. У цьому випадку ми отримуємо можливість «вимірювати відстань» між будь-яким двома точками на цій прямій. 
Отже, вказавши на прямій довільні дві точки метрична структура надає можливість визначити «встановлену розмірну відстань» між ними. Відображеннями, що зберігають метричну структуру прямої, автоморфізмами цієї структури, - слугують зрушення і відображення відносно вибраних точок. Зрушення створюють підгрупу цієї групи. Чи існує на прямій щось таке, що зберігалось би при зрушеннях, і могло б зберігатись при зрушеннях, але могло б змінюватись при інших автоморфізмах?

Так, прямій існує ще одна, більш «первинна» (по відношенню до метричної) структура - так звана структура порядку. Стоячи на прямій, можна відрізнити напрямок «наліво» від напрямку «направо», або, якщо уявити собі пряму у вигляді вісі часу, відрізнити минуле від майбутнього. Що назвати правим чи лівим, байдуже і залежить цілком від нашого смаку. Але якщо вибір зроблено, то пряма стає орієнтованою, а 1-вимірний економічний простір одномірно орієнтованим. Орієнтацію можна визначати стрілкою, що вказує напрямок зліва направо або навпаки. Втім, достатньо визначити орієнтацію базисного (одиничного) відрізка, щоб знати як орієнтовані будь-які відрізки і вся пряма (рис. 1).

Видно, що одновимірний економічний простір можна орієнтувати двома способами. При одній орієнтації точка а лежить зліва від точки $\mathbf{b}$, при другій точка $\mathbf{b}$ лежить зліва від точки $\mathbf{a}$. Обидві орієнтації прямо протилежні.

1)



2)

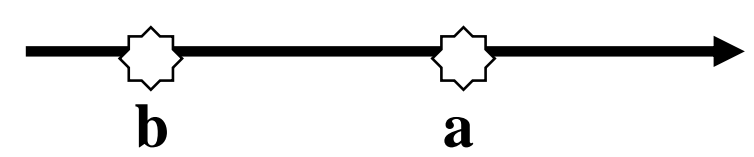

Рис. 1. Визначення орієнтації стрілкою, що вказує напрямок:

1) справа наліво або 2) навпаки, зліва направо

Джерело: розроблено автором

У чому полягає різниця між зрушеннями і відображеннями на прямі й? При зрушеннях орієнтація прямої зберігається, а при відображеннях змінюється на протилежне. Якщо пряма наділена двома структурами метричною структурою і структурою порядку, то група автоморфізмів прямої звужується: в ній залишаються тільки зрушення. Група автоморфізмів 
метричної прямої містить зрушення і відображення відносно точок, група автоморфізмів метричної орієнтованої прямої містить тільки зрушення

Двовимірний економічний орієнтований простір. Визначимо двовимірний економічний простір - площину, що наділена звичайною метричною структурою (для будь-якої пари точок площини метрична відстань визначена звичайно). Група автоморфізмів в у цьому випадку складається із зрушень, поворотів i переносів із відображеннями. Чи можна ввести на площині структуру близькості?

Якщо стоячи на площині розвести руки в сторони, то можна намітити пряму, що зорієнтована, наприклад, направо. Рухаючись вздовж цієї прямої можна запозичити для точок площини структуру близькості, що введена на прямій. (На вісі часу нам просто не залишається нічого іншого: повернутись назад у часі неможливо).

В економічному двомірному просторі із метриками (економічними вимірами ціннісно-часових величин метричної структури) по обом вісям, будувати структуру близькості потрібно індивідуально мислено для кожної пари вимірів. Створити орієнтованість економічно-метричної площини (двомірного економічного простору) найкраще буде за допомогою замкненої лінії на цій площині, коли дивлячись на площину зверху, як на циферблат годинника - стрілка зліва направо за годинниковою стрілкою, стрілка справа наліво проти годинникової стрілки.

Мислення уявлення про визначення однозначності метричного орієнтованого економічного простору досить є складним. При чому, на кожний неорієнтований економічно-метрично визначений двомірний (у вигляді площини) простір припадає лише два орієнтованих (рис. 2).

Визначення орієнтації двомірного метрично визначеного економічного простору не $\epsilon$ примхою. Прикладне значення такого поняття важлива можливість визначити динаміку різнонаправлених динамічних економічних процесів, коли вдається запровадити виміри параметрів не скалярними, а вже векторними величинами. Векторність процесів можливо визначити тільки завдяки наявності орієнтованості двовимірного метрично визначеного економічного простору. Евклід знехтував орієнтацією площини. Всі свої побудови він виконував на неорієтованій площині. Це призводило i призводить в геометрії, наприклад до складнощів у використанні багатьох теорем. В даній статті ми зупинились лише на спробі визначення поняття орієнтації двомірного метрично визначеного економічного простору. Питання властивостей його метричної структури й структури порядку та формування їх моделей $є$ завданням наступних досліджень. 


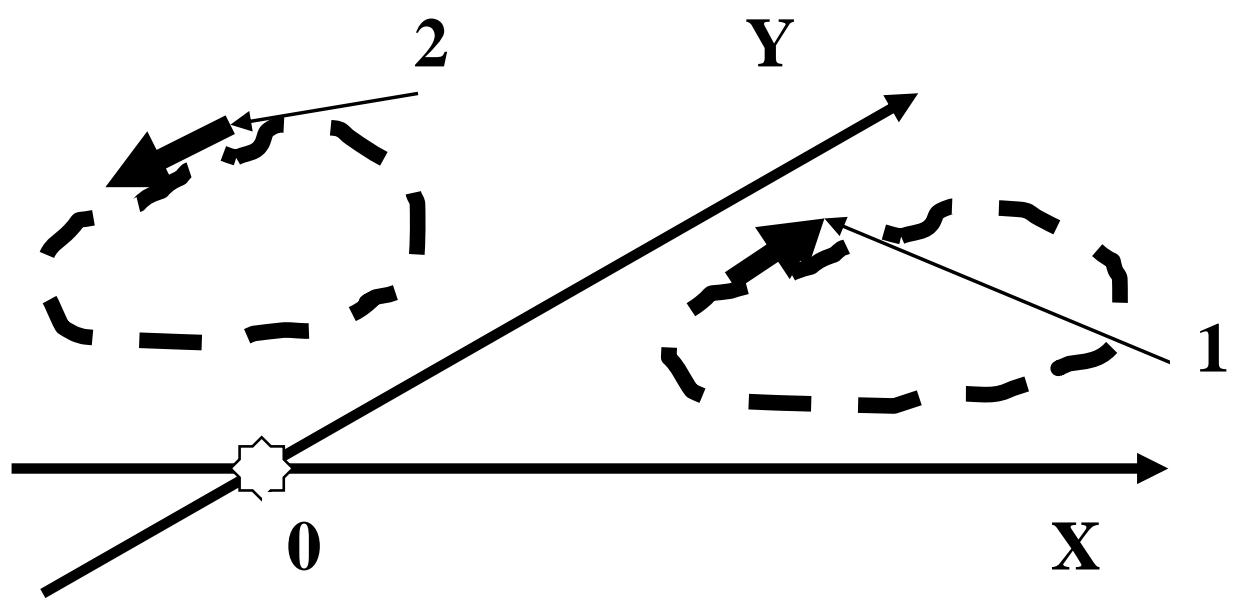

Рис. 2. Орієнтованість економічно-метричної площини ХОY

Примітка: стрілка 1 вказує орієнтацію двовимірного простору - площини - зліва направо за годинниковою стрілкою, стрілка 2 - справа наліво проти годинникової стрілки Джерело: розроблено автором

Тривимірний економічний оріснтований простір. Питання визначення структури порядку тривимірного (й в подальшому кожного наступного $n-$ вимірного) економічного простору має зростаючу складність. Разом 3 тим введення множинної економічно визначеної метричності такого простору не $\epsilon$ складним. Отже, до двох виділених елементів орієнтування площини в тривімірному економічному орієнованому просторі додається третій елемент. Тривимірний простір можна «натягнути» лише на три й тільки на три виділених напрямки (рис. 3). 

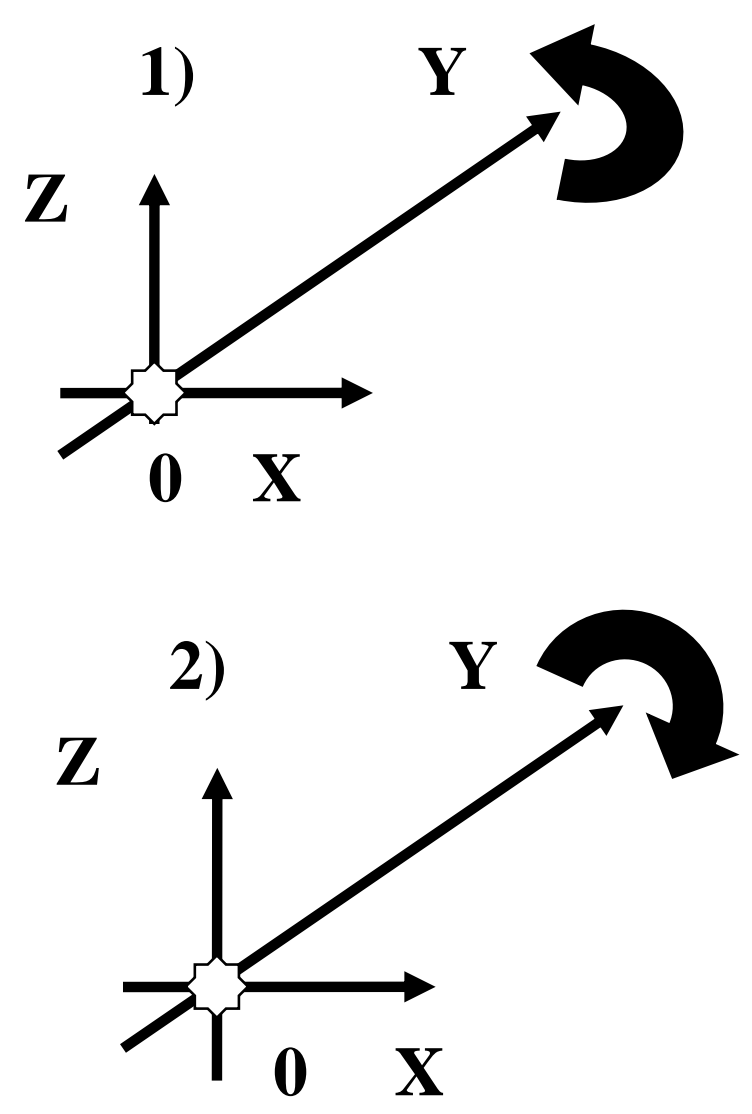

Рис. 3. Тривимірний орієнтований простір

Примітка: 1) правий гвинт, якщо нитки різьби ідуть зліва направо і вверх; 2) лівий гвинт, якщо нитки різьби ідуть зліва направо і вниз.

\section{Джерело: розроблено автором}

Їх поєднує таке. Перед нами знаходиться, наприклад, правий гвинт, якщо нитки різьби ідуть зліва направо і вверх. Це визначення напряму не залежить від нашого розташування відносно гвинта. На кожний неорієнтований тривимірний простір припадає два орієнтованих. Вони відрізняються лише визначенням типу правого чи лівого гвинта, яким ми визначимо рух по будьякій із трьох вісей. Цей рух визначить орієнтування простору по двом іншим взаємоортогональним осям рухів обертання за часовою стрілкою в природних явищах.

Отже, визначення структури порядку в економічному просторі таке.

Якщо задається орієнтація на прямій, вибирається на ній дві точки і визначаючи одну з них вказуємо, наприклад: « Ця лежить зліва». 
Коли визначаємо орієнтацію на поверхні, віддаємо перевагу визначеному напрямку обертання, наприклад, пояснюючи як належить здійснити поворот «наліво».

Простір набуває орієнтацію тоді, коли ми вказуємо гвинт, наприклад, той, який ми звемо «лівий гвинт». На кожний неорієнтований метрично визначений простір припадає два орієнтованих. То, що в одному 3 них визначає лівий гвинт, в іншому визначає правий. В такому орієнтованому просторі із автоморфізмів залишаються лише гвинтові рухи.

Який простір, орієнтований чи неорієнтований, необхідний для опису явищ природи, до яких відносяться також і економічні явища при формуванні інноваційних бізнес-структур?

Можна не сумніватись: нам абсолютно необхідний орієнтований простір. В неоріснтованому просторі не можливо скористатись навіть штопором, щоб відкоркувати пляшку вина. Фізик також має необхідність користатись орієнтованим простором, як і інженер-механік, бо їм потрібні гвинти та гайки. Біохіміки не можуть обійтись без орієнтованого простору при визначенні відрізняти рухи обертання вліво проти часової стрілки від протилежних.

Чи не є це все тільки нагромадженням випадковостей? Бо чи не можна нарізати штопор або гвинт в іншу сторону? Чи не могло б розвиватись життя, як би природні явища - оптично активні з'єднання були б спрямовані правостороннім обертанням. Але в природі де-факто існує тільки один тип гвинта. Але чи існує він де-юре? Чи необхідний орієнтований простір для формулювання загальних законів природи? В теорії електромагнетизму зустрічається правило «буравчика». Це правило дозволяє визначати завчасно, в яку сторону відхилиться магнітна стрілка в залежності від напрямку руху електричного струму: «якщо направити вісь правого штопору вздовж провідника і мислено вкручувати його за напрямом струму, то північний полюс магнітної стрілки відхилиться в ту сторону, в яку б його штовхнула ручка штопору».

Чи означає таке визнання правого гвинта де-юре у якості правила орієнтування рухів щодо визначення інших законів природи або суспільства (економіки)?

Висновки. Науковою новизною статті автора $\epsilon$ представлення можливості винахідливому інтелекту подальшої роботи у всіх його проявах, зокрема у намаганнях проникнути більш глибоко у можливості розкриття теоретичного та практичного значення результатів дослідження, у тому числі сутності економічних процесів, що можуть бути описані в межах понять теорії економічного орієнтованого простору, наділеного метричною структурою та на першому місці - структурою порядку, як це існує у фізичному світі. 
Автором статті вперше продемонстровано такі підходи до можливих рішень наукової проблеми формування економічного орієнтованого простору, які можуть породжувати отримання нових і навіть неочікуваних наукових результатів у майбутньому. Розглянуто зміст досить багатьох новацій щодо опису економічного простору, які неодмінно націлені на конкретне осягнення реальних економічних процесів та по типу підходу зовсім протилежний сучасному розумінню такого простору як геометричного.

Перспективою подальших наукових розробок за даним напрямом дослідження $є$ формування комплексної методології оцінювання стану розвитку економічного простору інноваційних бізнес-структур.

Матеріал статті може бути рекомендований для подальшого використання як основу формування нової парадигми формування понять економічного простору та теоретико-практичного застосування й розвитку інноваційно-орієнтованого управління на підприємствах різних галузей промисловості та інноваційних бізнес-структур.

\section{Література:}

1. Фукуяма Ф. Конец истории и последний человек. М.: АСТ; Ермак, 2004.

2. Бистряков І. К., Манцевич Ю. М. Використання простору у площині суспільних перетворень в Україні. Вісник НАН України, 2015, №11. С. 67-76.

3. Вернадський В. И. Научная мысль как планетарное явление. М.: Наука, 1991. - 436 с.

4. Андерсон А., Андерсон Д. Ворота в глобальную экономику. М.: Фазис, 2001. - 233 с.

5. Кастельс М. Информационная эпоха: экономика, общетво и культура. М.: ГУ ВШЭ, 2000. $-412 \mathrm{c}$.

6. Трубина Е. Г. Город в теории: опыты осмысления пространства. М.: НЛО, 2011. - 376 с.

7. Морозов О. Ф. Філософія нематеріальної потужності соціально-економічних систем. Частина І. // О. Ф. Морозов, Економіка і організація управління, 2014. - № 1(17) - №2 (18), - C. $180-188$.

8. Морозов О. Ф. Філософія нематеріальної потужності соціально-економічних систем. Частина II // О. Ф. Морозов, Економіка і організація управління, 2014. - № 3 (19) - №4 (20), - C. 180-189.

9. Морозов О. Ф. Формування системних ефектів економічних систем, наприклад, стартапів - частина 1. / О. Ф. Морозов, Т. О. Морозов, Економіст, 2016, №9, - С. 10-14.

10. Морозов О. Ф. Формування системних ефектів економічних систем, наприклад, стартапів. - Частина 2. / О. Ф. Морозов, Т. О. Морозов, Економіст, 2016, №10, - С. 40-47.

11. Vossler Karl. Spache und Wissenschaft//Geist und Kultur in der Sprache. - Heidelberg, 1925.

12. Speiser A. Klasische Stucke der Mathematik. - 1925. - 148 S. 